\title{
Modeling factors affecting the choice of telework and its impact on demand in transportation networks
}

Factores de modelado que afectan la elección del teletrabajo y su impacto en la demanda en las redes de transporte
Author:

Rambod Vakilian ${ }^{1}$

Ali Edrisi ${ }^{2 * *}$

\section{SCIENTIFIC RESEARCH}

How to cite this paper:

Vakilian. R., Edrisi. A. Modeling Factors Affecting the Choice of Telework and Its Impact on Demand in Transportation Networks. Tehran, Iran. Innovaciencia. 2019; 7 (2): 1-11. DOI:

http://dx.doi.org/10.15649/2346075X.772

Reception date:

Received: 28 January 2019

Accepted: 2 May 2019

Published: 25 October 2019

Keywords:

Teleworking, Transportation Demand, Logistic Regression, Latency, Travel Time

\section{ABSTRACT}

This research estimates the extent of using teleworking to mean the feasibility and appropriateness of this method of work for employees and professors according to their characteristics and features of career. The study population included university staff and professors in Tehran and data collection was carried out through 447 questionnaires. A logistic regression model was used to investigate the transport demand caused by teleworking. The results showed that various factors including history and percentage of telework and after that, the time delay of home-to-work and travel distance affected the model of transportation demand of professor's members. For the staffing community, it had the greatest impact on teleworking, history and percentage of telework, followed by travel distances, latency from work to home, and latency from home to work.

Corresponding author.

MSc, Civil Engineering Faculty, K. N. Toosi University of Technology, Tehran, Iran, e-mail: rambod.vakilian@gmail.com

2* Assistant Professor, Civil Engineering Faculty, K. N. Toosi University of Technology, Tehran, Iran. e-mail: edrisi@kntu.ac.ir 


\section{INTRODUCTION}

Teleworking is a new concept that includes many relevant and important topics and basis. One of these important bases in relation to teleworking of impact essay is the study of its positive and negative effects from different perspectives such as social, economic, cultural, and environmental and transport ${ }^{[1]}$. The factor that ultimately determines the effects of the telework operation is the rate of application and use. Teleworking has been existed for many years, and with the advent of information technology (Internet, etc.), human life has been expanded significantly with it. Teleworking today is often introduced as a tool for improving sustainability with reduced environmental, economic and social impacts. At present, teleworking, however, has not yet been introduced and applied as a major plan in the offices of Iran.

The history of computer-based telework has begun since 1970. The governments and large industrial companies in the world that seek to increase productivity and enhance the quality of their employees' life have interested in this phenomenon and have gained many benefits for themselves and their employees. However, the average Internet telephony in the world is less than $5 \%$, and is only higher in the United States due to the existence of computer companies that teleworking are highly compatible with their business philosophy. Teleworking in Europe has begun since 1980 following the outbreak of unemployment. In the next few years, telecoms are expected to introduce as part of the expansion of the global network economy and the widespread growth of organizations across sectors and businesses. Existential philosophy of teleworking is to bring the workplace to the employees' home, given that traditional patterns of work, workplace, work time, and organizations and employer attitudes are in the seek of rapid improvement in information and communication technology ${ }^{[2,3]}$.

The main objective of this research is to investigate the fields of teleworking application regarding to the occupational characteristics of individuals. In order to achieve these goals, the effect of information and communication systems on decision making of Tehran citizens in business trips will be studied considering theoretical foundations of travel behavior as well as the acceptance of telework behavior considering the attitude of decision makers elements and other influential factors. The framework components of this research are staff and supervisors. The study of different sections of the theoretical framework and their relationship with each other is mainly based on modeling. The collection of data required for modeling is mainly through the design, compilation and distribution of the questionnaire. Since the knowledge of individuals about the phenomenon of teleworking is very low, only the description of the situation can be collected their opinions through the presentation of them.

Several important points distinguish this study from other studies. The first distinction is that the statistical framework in this study is unlike in similar studies in advanced countries, including public sector employees. Private companies are not the aim of this study due to causality, such as asset and insurance issues, less need for change, and lack of precise job description. Another distinction is that, in similar studies, the views of employers are of the highest priority in the process of employing telework as being able to provide this mode of work. In other words, the existence of this work option for employees depends on the employer's decision to provide it. If this method is not provided by employers, employees will not normally have the right to choose. If offered, researchers will review the selection of staff on how much they will be used based on their desirability and interest. However, the aim of this study is to optimize the extent of applying teleworking or its possibility. Based on the suitability of job activities and the feasibility of this method of work, the appropriate and optimal teleworking is estimated. In other words, the purpose of this study is to provide a central planning or systemic perspective for the whole of society rather than maximizing individual preferences. Another important distinction is the way of considering businesses. In this study, in order to make the research more generality and comprehensive, instead of using the type of business, its activities are used 
in analyzes. That is, first breaking and dividing the job into the elements and its activities, and then modeling the proportion of teleworking per day in a week based on these activities. Thus, for the different types of jobs, the degree of proper use or feasibility can be estimated. In this regard, there is no limit to the type of occupation, and new jobs that will be created in the future, and even the changing nature of the business, can be taken into account.

\section{REVIEW OF PREVIOUS RESEARCH}

In 2016, Botzoris et al. investigated sustained teleworking and transportation in critical economic conditions, in order to reduce the cost of transportation [4]. In 2017, Moeckel analyzed the impact of teleworking on the land use in transport and provided the number of days of telework to individuals in a model. The results of this study indicate that travel demand for work and nonbusiness trips to any work inside the home is greatly reduced, resulting in lower costs such as fuel consumption and the cost of traveling time and delay time, etc. ${ }^{5}$. In 2017, Lila et al. reviewed the impact of telework in urban areas in India. Their model results showed that the drop by $1.9 \%$ in per kilometers traveled and 3.5\% in hours of traveled in the first year and dropped by 3.2 to $6.10 \%$ in the next 5 years. On the other hand, the overall delay in the transportation network has reached a maximum of $6 \%$ in the first year and $9 \%$ in the next 5 years ${ }^{[6]}$. In 2017, Labedowiez and Urbanek have examined the communication and information technologies affecting the demand for transport, and had an investigation on the EU countries. The research aims to provide an analysis of the use of information and communication technologies by individuals and companies, including freight and passenger transportation processes in the European Union. This requires an examination of the wider relationship of communication and information technology and changes in demand services for people and companies. Based on this, teleworking was investigated as a new way of improving demand for transportation to reach the individual at work. The results showed that EU countries often achieved a good improvement in the Gross Domestic Product by using these technologies between 2000 and 2013, and the productivity of organizations and their impacts on transportation demand has been improved ${ }^{[7]}$. In 2017, Elldér investigated the relationship between telework on the structure of urban travel, and finds out how this relationship works. As urban structure is affected by the behavior of daily travel, telework can also be effective. Regression models can be used to examine the relationship between the two, based on the degree of experience of teleworking and the relative access of people from home to work as two variables enter in the model. The results of this study showed that the weakness in telework between urban structure and travels could be related. In this regard, it was found that the behavior of daily travels is more dependent on the characteristics of individuals than the distance from the home to the workplace ${ }^{[8]}$. In 2018, Ge et al. reviewed the model-based intelligence for distribution programs at workplaces. In this regard, telework and face-to-face communication have been examined from the perspective of the benefits and disadvantages. On the other hand, the amount of pollution and the number of times for referring to the delivery of work in telework with the presence of the individual in the workplace, the cost of transportation and travel to the workplace is then compared, based on the division of labor between teams 3 And 5 and without teams in the field of telework and presence at the workplace were reviewed and compared [9]. In 2018, Zhu et al. examined the dimensions of the city center on telework in employees' trip. The results of his modeling showed that the full effect on teleworking on daily trips is lower than urban centers, and both nonworking and working trips are not excluded from this rule ${ }^{[10]}$. In 2018, Shabanpour et al. analyzed telework behavior and its effects on the environment and demand for travel, and found that 12 percent of staff in the Chicago area was flexible in terms of their work schedules, and telework could reduce their total distance traveled and their travel time of $0.69 \%$ and $2.09 \%$, respectively. A comparison showed that this policy could increase greenhouse gas emissions and air pollutants by 0.71 and 1.14 percent, respectively. These effects will be higher at peak hours ${ }^{[11]}$. In 2018, de Abrau et al. reviewed the effects of home-based telework on travel to 
reduce travel for one to two occupations $\frac{[12]}{}$. In 2018, Silva and Melo addressed the patterns of homebased telework, travel behavior and land use with a single-job analysis ${ }^{[13]}$. In 2018, Akbary and Borng reviewed the views of managers and librarians in Kerman province for telework with consideration of their interests and obstacles and ways to develop it to prevent delays in transit of people to travel ${ }^{[14]}$. In 2018, Giovanis presented a relationship between telework, traffic and air pollution ${ }^{[15]}$. In 2018, Suarlan provided telework for servants based on issues, strengths, and weaknesses to reduce travel time to go to work ${ }^{[16]}$.

Regarding the history of the present research, it can be said that so far and especially in Iran, to provide mathematical relation for the effective influence of the factors on the choice of telework and its effect on the demand for transport in the form of a dynamic model, no comprehensive research has been carried out. In addition, most research on organizational telework has been conducted, the impact on the organization and staff has been monitored, and the important thing is traveling to work from home, which should be given more attention. Few researches have been made about this issue, but a more comprehensive examination and especially the factors affecting the choice of teleworking and its impact on transportation demand are needed. In this regard, in several researches, several factors have been examined and the requirement to consider more factors that are effective is needed. The present research seeks to model these factors in the form of a mathematical model based on the perceptions of community members in different strata and with the view employer and staff.

The present research is aimed at field survey of questionnaire and presents a model that is appropriate in this field and has caused the present research to be field-analytic. The features and dimensions of occupations as factors affecting telework possibility are able to explain the teleworking demand. This concept is designed to estimate the appropriate telework rate, but it is not a simple task to collect the information needed to implement the related models. Due to the limited information about the occupations, especially in the wider organization, after the study and library studies, the status and organizational unit are used in this study. In other words, an abstract job approach with these variables is used to collect the necessary data and generalize to the community. In order to establish a relationship between the factors affecting the choice of telework and its impact on demand in transportation networks, it is necessary to examine the various effective factors in addition to what has been achieved in previous studies.

\section{COLLECTING DATA}

The methodology of the present research with regard to categorize the research methods is field-library-analytical research method in which mathematical analysis, statistical analysis, field study and questionnaire will be discussed. Therefore, the research method can be summarized as follows: 1) Review of the literature of its research and theoretical foundations as well as previous studies on telework and modeling of the factors affecting the choice of telework and its impact on demand in transportation networks, especially in Tehran. 2) Design and Setting up a questionnaire and collecting data based on a field study 3) Modeling and statistical analysis based on the variables desired using a logistic regression model 4) Validating the results and conclusions and suggestions.

\subsection{Introduction Variables and Data Descriptions}

In this section, the collected data around the present research is presented in the form of independent and dependent variables. The collected data includes personal data such as age, gender, marital status, number of young children, level of education, monthly income, work history, status of residence, telework history, driving license and travel details such as distance traveled, monthly travel cost, hometo-work travel time, home-to-home latency, homework travel time, work-to-home time delay, working conditions such as percentages of teleworking, work shift, number of weekly working days per week, approach to the arriving workplace, satisfaction with transportation to reach the workplace, depend on the choice of transportation mode to climate change as independent variables. The dependent variable is also demand for transportation. 


\subsection{Sampling and data preparation}

Samples were selected from individuals of different ages in the 5-year intervals, and the sample size was as much as the total population based on the categories mentioned above. In this study, for collecting data, a survey-field survey method was used for research purposes and the tool used was a questionnaire. Finally, using the software 23.0SPSS, the information was analyzed and the statistical tests were used to examine the effect of different variables on transport demand. The number of data used in this study was more than the minimum recommended according to the statistical population and the sample obtained from the Cochran formula. In this research, a questionnaire was used to collect data. In this regard, a summary of the data collection is presented in Table (1).

Table 1- The number of distributed and collected questionnaires from the statistical population

\begin{tabular}{ccccc}
\hline Carreer type & $\begin{array}{c}\text { The total number of } \\
\text { collected questionnaires }\end{array}$ & $\begin{array}{c}\text { The number of applicable } \\
\text { questionnaires }\end{array}$ & unacceptable & $\begin{array}{c}\text { Unfilled } \\
\text { questionnaires }\end{array}$ \\
\hline Employees & 168 & 99 & 8 & 61 \\
Professors & 276 & 201 & 11 & 67 \\
Total & 447 & 300 & 19 & 128 \\
\hline
\end{tabular}

As shown in Table (1), about $67 \%$ of the questionnaires were filled in. Additionally, the general specifications, travel specifications and working

Table 2- General Specifications of Respondents

\begin{tabular}{|c|c|c|c|}
\hline Main group & subgroup & $\begin{array}{c}\text { General } \\
\text { specifications } \\
\text { of employee } \\
\text { (percent) }\end{array}$ & $\begin{array}{c}\text { General } \\
\text { specifications } \\
\text { of professors } \\
\text { (percent) }\end{array}$ \\
\hline \multirow{2}{*}{ Gender } & Female & 19.6 & 41.0 \\
\hline & male & 80.4 & 59.0 \\
\hline \multirow{7}{*}{ Age } & 25-21 years & 20.6 & 1.5 \\
\hline & $30-26$ years & 27.8 & 9.0 \\
\hline & $31-35$ years & 18.6 & 15.0 \\
\hline & 40-36 years & 14.4 & 21.0 \\
\hline & $45-41$ years & 13.4 & 21.5 \\
\hline & $50-46$ years & 5.2 & 14.4 \\
\hline & $>50$ years & 0 & 17.5 \\
\hline \multirow{6}{*}{$\begin{array}{l}\text { Level of } \\
\text { education }\end{array}$} & $\begin{array}{l}\text { Under } \\
\text { diploma }\end{array}$ & 22.2 & 0 \\
\hline & Diploma & 7.1 & 0 \\
\hline & Associate & 23.3 & 0 \\
\hline & Bachelor & 40.4 & 3.5 \\
\hline & Masters & 7.1 & 40.8 \\
\hline & P.H.D & 0 & 55.7 \\
\hline
\end{tabular}

conditions of individuals are described in Tables (2) and (3).

Table 2- (Continuated)

\begin{tabular}{|c|c|c|c|}
\hline Main group & Subgroup & $\begin{array}{c}\text { General } \\
\text { specifications } \\
\text { of employee } \\
\text { (percent) }\end{array}$ & $\begin{array}{l}\text { General } \\
\text { specifications } \\
\text { of professors } \\
\text { (percent) }\end{array}$ \\
\hline \multirow{2}{*}{ Marital status } & Single & 32.7 & 13.9 \\
\hline & Married & 67.4 & 86.1 \\
\hline \multirow{5}{*}{$\begin{array}{l}\text { The number of } \\
\text { young } \\
\text { children under } \\
18 \text { years }\end{array}$} & None & 10.2 & 8.7 \\
\hline & 1 & 33.3 & 24.1 \\
\hline & 2 & 32.6 & 35.1 \\
\hline & 3 & 17.4 & 20.6 \\
\hline & $>3$ & 6.5 & 11.5 \\
\hline \multirow{2}{*}{$\begin{array}{l}\text { Driving } \\
\text { license }\end{array}$} & Yes & 89.9 & 85.3 \\
\hline & No & 10.1 & 14.7 \\
\hline \multirow{5}{*}{$\begin{array}{l}\text { Monthly } \\
\text { income }\end{array}$} & $\begin{array}{l}<1 \text { million } \\
\text { toman }\end{array}$ & 0 & 0 \\
\hline & $\begin{array}{l}\text { 2-1 million } \\
\text { toman }\end{array}$ & 35.7 & 0 \\
\hline & $\begin{array}{l}\text { 4-2 million } \\
\text { toman }\end{array}$ & 55.1 & 16.6 \\
\hline & $\begin{array}{l}\text { 6-4 million } \\
\text { toman }\end{array}$ & 5.1 & 33.2 \\
\hline & $\begin{array}{c}>6 \text { million } \\
\text { toman }\end{array}$ & 4.1 & \\
\hline
\end{tabular}


Table 3- Travel Specifications and Working

Conditions of the Respondents

\begin{tabular}{|c|c|c|c|c|c|c|c|}
\hline $\begin{array}{l}\text { Main } \\
\text { group }\end{array}$ & Subgroup & $\begin{array}{c}\text { Travel } \\
\text { specifications } \\
\text { of employees } \\
\text { (percent) }\end{array}$ & $\begin{array}{c}\text { Travel } \\
\text { specifications } \\
\text { of professors } \\
\text { (percent) }\end{array}$ & Main group & Subgroup & $\begin{array}{l}\text { Travel } \\
\text { specifications } \\
\text { of employee } \\
\text { (percent) }\end{array}$ & $\begin{array}{c}\text { Travel } \\
\text { specifications } \\
\text { of professors } \\
\text { (percent) }\end{array}$ \\
\hline \multirow{7}{*}{$\begin{array}{l}\text { Travel } \\
\text { distance }\end{array}$} & 10 and $<10 \mathrm{~km}$ & 47.9 & 56.0 & \multirow{5}{*}{$\begin{array}{c}\text { Latency of } \\
\text { work to home }\end{array}$} & Without delay & 16.3 & 22.8 \\
\hline & $11-20 \mathrm{~km}$ & 19.8 & 16.1 & & $<10 \min$ & 33.7 & 33.5 \\
\hline & $21-30 \mathrm{~km}$ & 20.8 & 10.9 & & $11-20 \mathrm{~min}$ & 30.6 & 23.4 \\
\hline & $31-40 \mathrm{~km}$ & 3.1 & 4.7 & & $21-30 \mathrm{~min}$ & 11.2 & 11.7 \\
\hline & $41-50 \mathrm{~km}$ & 5.2 & 9.3 & & $>30 \mathrm{~min}$ & 8.1 & 8.6 \\
\hline & $51-60 \mathrm{~km}$ & 2.1 & 2.0 & \multirow{7}{*}{$\begin{array}{l}\text { The } \\
\text { percentage of } \\
\text { telework }\end{array}$} & None & 20 & 10 \\
\hline & $>60 \mathrm{~km}$ & 1 & 1.1 & & $<10$ percent & 10 & 10 \\
\hline \multirow{4}{*}{$\begin{array}{l}\text { Monthly } \\
\text { travel fee }\end{array}$} & $<100000$ toman & 52 & 30.0 & & $11-20$ percent & 11.3 & 14.3 \\
\hline & toman & 36.7 & 48.0 & & $21-40$ percent & 21 & 29.7 \\
\hline & $\begin{array}{c}300000-200000 \\
\text { toman }\end{array}$ & 10.3 & 18.0 & & 41-60 & 15.2 & 22.4 \\
\hline & $>300000$ toman & 1 & 4.0 & & 61-80 percent & 7 & 5.4 \\
\hline \multirow{5}{*}{$\begin{array}{c}\text { Home } \\
\text { travel } \\
\text { time to } \\
\text { work }\end{array}$} & $\begin{array}{l}15 \min \\
\text { and }<15 \mathrm{~min}\end{array}$ & 36.7 & 33.5 & & $>80$ percent & 15.5 & 8.2 \\
\hline & $16-30 \mathrm{~min}$ & 32.7 & 37.6 & \multirow{4}{*}{ Shift work } & Morning & 68 & 50 \\
\hline & $31-45 \min$ & 11.2 & 7.6 & & Aftemoon & 15 & 20 \\
\hline & $46-60 \mathrm{~min}$ & 9.2 & 11.7 & & Evening & 7 & 30 \\
\hline & $>60 \mathrm{~min}$ & 6.1 & 4.6 & & Night & 10 & 0 \\
\hline \multirow{7}{*}{$\begin{array}{c}\text { Number } \\
\text { of } \\
\text { working } \\
\text { days per } \\
\text { week }\end{array}$} & 1 & 4.2 & 4.3 & \multirow{6}{*}{$\begin{array}{l}\text { Method of } \\
\text { getting to } \\
\text { work }\end{array}$} & Car & 45 & 72 \\
\hline & 2 & 6.0 & 15.2 & & Taxi & 21 & 15 \\
\hline & 3 & 8.8 & 50.1 & & Bus & 10 & 5 \\
\hline & 4 & 16 & 24.4 & & Bike & 0 & 0 \\
\hline & 5 & 40 & 4 & & Motorcycle & 14 & 0 \\
\hline & 6 & 20 & 2 & & telework & 10 & 8 \\
\hline & 7 & 5 & 0 & \multirow{5}{*}{$\begin{array}{l}\text { Depending } \\
\text { on the choice } \\
\text { of shipping } \\
\text { mode to } \\
\text { climate } \\
\text { change }\end{array}$} & dependent & 60 & 55 \\
\hline \multirow{5}{*}{$\begin{array}{l}\text { Satisfaction } \\
\text { with } \\
\text { shipping } \\
\text { to get to } \\
\text { work }\end{array}$} & Very much & 5 & 10 & & & & \\
\hline & Much & 6 & 15 & & & & \\
\hline & Medium & 40 & 35 & & independent & 40 & 45 \\
\hline & Little & 35 & 20 & & & & \\
\hline & Very little & 14 & 20 & \multirow{9}{*}{$\begin{array}{c}\text { Work } \\
\text { experience } \\
\text { (year) }\end{array}$} & $<5$ years & 15 & 5 \\
\hline \multirow{3}{*}{$\begin{array}{l}\text { Living } \\
\text { status }\end{array}$} & Personal & 22 & 25 & & 5-10 years & 20 & 22 \\
\hline & Lessee & 45 & 55 & & 11 - 15 years & 30 & 35 \\
\hline & other & 33 & 20 & & 16 - 20 years & 13 & 13 \\
\hline \multirow{5}{*}{$\begin{array}{l}\text { Telework } \\
\text { experience }\end{array}$} & None & 48 & 12 & & $21-25$ years & 10 & 15 \\
\hline & $<1$ years & 12 & 30 & & 26 - 30 years & 7 & 10 \\
\hline & 1-2 years & 21.3 & 18.3 & & $>30$ years & 5 & 0 \\
\hline & 2-3 years & 13.7 & 29.7 & & & & \\
\hline & $>3$ years & 5 & 10 & & & & \\
\hline
\end{tabular}

Table 3- (Continuated) 
4- MODELLING AND INTERPRETATION OF RESULTS

There are different methods for modeling and analyzing transport issues as well as factors and parameters affecting it such as traffic, economic and social parameters. In this research, logistic regression model was used to model the variables based on the considered variables. First, the model was provided based on multivariate logistic regression analysis and then the results of the modeling were discussed.
In tables (4) and (5), the coefficients and their significance level are shown for significant variables and interactions. In addition, in these tables, the significance of variables, their levels, and the coefficients of each variable (B) are presented with standard deviation error. These tables are compared by chance ratios. It should be noted that in the tables presented, only variables that were effective on the demand for telework were provided based on being significance.

Table 4- coefficients and significant level for their variables and significant correlations for the professors

\begin{tabular}{|c|c|c|c|c|c|}
\hline Variables & B & Std. Eror & Wald & Sig. & OR $(\operatorname{Exp}(B)$ \\
\hline (Constant) & -0.4 & 1.429 & 0.078 & 0.02 & \\
\hline Monthly income MI & -1.202 & 0.744 & 2.606 & 0.006 & 0.301 \\
\hline The number of children $<18$ years $\mathrm{NC}$ & -1.754 & 0.554 & 10.025 & 0.002 & 0.776 \\
\hline Travel distance TD & 0.615 & 0.370 & 2.755 & 0.017 & 1.849 \\
\hline Travel time from home to work TTHW & 0.025 & 0.342 & 0.006 & 0.041 & 1.026 \\
\hline Delay time from home to work DTHW & 0.621 & 0.315 & 3.883 & 0.049 & 1.860 \\
\hline Delay time from work to home DTWH & -0.125 & 0.377 & 0.109 & 0.041 & 0.883 \\
\hline Monthly travel cost MTC & -0.087 & 0.296 & 0.085 & 0.020 & 0.917 \\
\hline Telework percentage TWP & 2.832 & 1.635 & 2.999 & 0.033 & 16.976 \\
\hline The number of workdays NW & 0.427 & 0.352 & 1.473 & 0.025 & 1.532 \\
\hline Method of getting to work WM & 0.025 & 0.342 & 0.006 & 0.041 & 1.026 \\
\hline Habitat position HP & 0.01 & 0.314 & 0.001 & 0.015 & 1.01 \\
\hline Telework history (years) TWH & 2.513 & 0.718 & 12.249 & 0.000 & 12.340 \\
\hline
\end{tabular}

The general model for the influence of variables on telework demand for professors is described in equation (1)

(1) $\mathrm{LN}$ (DOT1) $=-1.202 \mathrm{MI}-1.754 \mathrm{NC}+0.615 \mathrm{TD}+0.025 \mathrm{~T} T H W+0.621 \mathrm{DTHW}$ $-0.125 \mathrm{DTWH}-0.087 \mathrm{MTC}+2.832 \mathrm{TWP}+0.427 \mathrm{NW}+0.025 \mathrm{WM}+0.010 \mathrm{HP}+2.513 \mathrm{TWH}-0.400$

In above equation, DOT1 is the amount of telework demand for professors, and other variables are specified in Table 4. From Table 4, it can be concluded that the history and percentage of teleworking, and the time delay between home and work and travel distance have the greatest impact on teleworking demand. The monthly income variable is given to people who earn more than 6 million toman per month and whose coefficient is the negative in the model. The results show that the probability of choosing home telework is 3.32 times lower compare to those with income $(\mathrm{OR}=0.301=0.332)$. The number of young children under the age of 18 variable is for people who have more than three children younger than 18. The results show that the probability of choosing home telework in this group is 1.29 times less than people who have children under the age of $18(\mathrm{OR}=0.776=1.29)$. Distance travel is also an influential variable. This variable is for those whose travel distance is more than 60 kilometers per day. 
The results show that for this group, the probability of choosing home telework is about 1.849 times less than travel distance. The next variable is the travel time of the home to the workplace. This variable is for those whose travel time is more than 1 hour and the coefficient of this variable in the model is positive. For people in this group, the probability of choosing a home-based telework service is about 1.126 times more than travel time. The time delay from home to work is also for people with a travel distance of more than 30 minutes. For people in this group, the probability of choosing home telework is about 1.860 times less than the delay time.

The time delay variable from work to home is for people whose travel distance is more than 30 minutes and the coefficient of this variable is negative in the model. The results show that the probability of home-based telephony is about 132.1 times less than delay time. The monthly travel cost is also examined. This variable relates to people whose monthly travel cost is more than 300 thousand toman, and the coefficient of this variable is negative in the model. Therefore, for people in this group, the probability of choosing home telephony is about 0.11 times less than monthly travel costs. The other variable is the percentage of telework. This variable represents those whose percentage of telework is more than
$80 \%$ and the coefficient of this variable is positive in the model. The results show that the probability of choosing home telephony is 16.976 times lower than that of telework percentage. The number of working days per week is another variable that has been reviewed. This variable refers to people whose number of working days is the total of the week and the coefficient of this variable is positive in the model. The results show that for this group, the probability of choosing home telework is about 1.532 times less than that of telework percentage. The next variable is the approach to getting to work that shows people who are teleworking and are at home. The results show that for this group, the probability of choosing home telephony is about 1.026 times higher than the use of vehicles such as taxis and buses, and so on. Habitat position has also been studied. This variable refers to people whose residence status is other than the tenant and owner of the home and the coefficient of this variable is positive in the model. The results indicate that for this group, the probability of choosing home telework is about 0.101 times that of tenant and private owner. The teleworking history is for people whose work history exceeds 3 years and the coefficient of this variable is positive in the model. The results show that for the group, the probability of choosing home teleworking is about 3,408 times less than the teleworking experience.

Table 5- The coefficients and significance level for variables and their significant correlation for the staff

\begin{tabular}{cccccc}
\hline Variables & B & Std. Eror & Wald & Sig. & OR (Exp(B) \\
\hline (Constant) & 2.386 & 1.278 & 2.487 & 0.012 & \\
Monthly income MI & -2.046 & 0.625 & 10.701 & 0.001 & 0.129 \\
The number of children <18 years NC & -1.105 & 0.474 & 5.434 & 0.02 & 0.22 \\
Travel distance TD & 0.878 & 0.352 & 6.227 & 0.013 & 2.406 \\
Travel time from home to work TTHW & -0.428 & 0.306 & 1.958 & 0.012 & 0.652 \\
Delay time from home to work DTHW & 0.124 & 0.292 & 0.180 & 0.022 & 1.132 \\
Delay time from work to home DTWH & 0.404 & 0.340 & 1.413 & 0.035 & 1.498 \\
Monthly travel cost MTC & -0.630 & 0.280 & 5.076 & 0.024 & 0.533 \\
Telework percentage TWP & 2.254 & 1.451 & 2.411 & 0.021 & 9.522 \\
The number of workdays NW & 0.01 & 0.314 & 0.001 & 0.025 & 1.01 \\
Method of getting to work WM & 0.025 & 0.342 & 0.006 & 0.041 & 1.026 \\
Habitat position HP & -0.077 & 0.421 & 0.034 & 0.014 & 0.926 \\
Telework history (years) TWH & 1.907 & 0.581 & 10.750 & 0.001 & 6.730 \\
\hline
\end{tabular}


The general model for the impact of variables on teleworking demand for employees is the following equation (2).

$$
\begin{aligned}
& \text { (2) } \mathrm{LN}(\mathrm{DOT} 2)=-2.046 \mathrm{MI}-1.105 \mathrm{NC}+0.878 \mathrm{TD}-0.428 \mathrm{TTHW}+0.124 \mathrm{DTHW} \\
& +0.404 \mathrm{DTWH}-0.630 \mathrm{MTC}+2.254 \mathrm{TWP}+0.010 \mathrm{NW}+0.025 \mathrm{WM}-0.077 \mathrm{HP}+1.907 \mathrm{TWH}+2.386
\end{aligned}
$$

In the above, DOT2 is the teleworking rate for employees, and other variables are specified in Table (5). From Table 5, it can be concluded that the history and percent of teleworking, and then the distance of travel, the time delay from work to home and the time delay from home to work have the greatest impact on the demand for teleworking respectively. The variables in this table are defined as in Table (4), and the probability of selecting telework is calculated by each group as before. For example, in the case of the monthly income variable, the results show that the probability of choosing telework at home for this group is 752.7 times less than people with income $(\mathrm{OR}=1 / 0.129=7.752)$. In addition, for travel variable, the probability of choosing home telework is about 2.406 times less than the trip distance $(\mathrm{OR}=2.406)$.
As can be seen in tables (4) and (5), the significance values of statistics indicate that all variables with their levels have a significant statistical effect (Sig <0.05), or in other words some independent variables included in the model are able to predict the variation of the dependent variable (teleworking demand) and the ability of predicting them at a level less than 0.05 is significant. Table 6 shows the results of two statistics of the logarithm of likelihood function and the coefficient of determination re of the pseudo (including the Cox and Neel R Square and the Nagelkerke coefficient of determination). The lower the statistic values of the logarithm likelihood function indicating the ability of the model to predict the variance of dependent variable. The values of the coefficient of determination of pseudo vary between zero and one, and values greater than 0.15 for these coefficients indicate that the model is suitable for fitting.

Table 6- The results of two statistics of the logarithm likelihood function and the coefficient of determination of pseudo for the professors and staff

\begin{tabular}{cccc}
\hline & Nagelkerke R Square & Cox \& Snell R Square & -2 Log Likelihood \\
\hline professors & 0.491 & 0.429 & 226.243 \\
staff & 0.581 & 0.502 & 86.415 \\
\hline
\end{tabular}

In the logistic regression model, since the dependent variable has two values of 0 and 1 , it is impossible to use the least squares method to estimate the coefficients of the model, hence the maximum likelihood method for estimating the function with the highest ability in the prediction of the probability of a dependent variable based on independent variables will be used. In the logistic regression, since it is difficult to calculate the exact amount of the coefficient of determination, so determine the pseudo determination coefficients was used to show how independent variables could explain the variance of the dependent variable. The number of Pseudo determination coefficients is very high, but the two more well-known coefficients are the Cox and Snell coefficients, and the coefficient of determination of the Nagelkerke. The values of the coefficient of determination of the Nagelkerke are changed between 0 and 1 and values greater than 0.15 for this coefficient indicate the acceptable fit of the model. Cox and Snell coefficients with the values of 0.429, 0 and409 and Nagelkerke with 0.491 and 0.581 for 
both faculty members and staff indicated that the prediction of the model in terms of the explanation and prediction of the dependent variable by the independent variables to this rate have been showed.

\section{CONCLUSION}

In this paper, we obtained a correlation for travel demand using regression model based on independent variables in two professors and employees. Among the variables studied, those with an appropriate significant level were presented in the model. Meanwhile, according to the results, it can be seen that for the professors' community, the history and percentage of teleworking, the time delay between home and work, and the distance traveled in the model related to the transport demand of this community had the greatest impact on the demand for telework. On the other hand, in the employees' community, history and percentage of teleworking, followed by travel distance, time delay from work to home, and latency from home to work had the greatest impact on teleworking demand.

It is worth noting that this research is in line with the research of Rashedi et al. in 2017 and with considering more variables and its localization, it has tried to determine the factors affecting the demand for transportation for the choice of teleworking. Significant effective variables in this research that are included in the model are: monthly income, the number of young children under 18 years of age, travel distance, home-to-home travel time, home-towork delay, work-to-home delay, the monthly travel cost, the percentage of teleworking, the number of working days per week, the method of reaching the work place, habitat position, the length of the telework to the year.

It can be concluded that the telework plan in a country that does not have the infrastructure to applying the project is not useful. One of the problems with this project is that employers believe that teleworking reduces the sense of responsibility of employees. One of the main problems with the implementation of the telework plan is to break the organizational relationship between the staff of the offices. In other words, getting employees away from their workplace reduces their sense of belonging and can reduce the sense of responsibility of employees. Another issue that needs to be addressed is the difficulty of communicating between teleworkers and customers. In many cases, customer need to communicate directly with employees, but due to the implementation of the telework plan, this will not be possible. Another point to be noted is the reduction in staff monitoring. In other words, in a country where, despite the supervision of employees, the shortage of work hours is quite tangible, it is unclear what will happen without the supervision of employees. It should also be noted that telework is considered only for research purposes. It is recommended that a telework plan should be considered for professors and academic staff by considering the trust between employees and employers, as well as consideration of rewards or other benefits for employees, and setting a time limit for the presentation and completion of their work. It is also possible to determine the percentage of certain workloads during the week or month and year by the employers, which will allow the finalization of the project to be carried out with pilot implementation and consideration of feedback.

The suggestions that could be made to continue this study include providing a mathematical relationship between the variables of this research on transport demand, which could help to complete this research. In addition, with the method used in this research for other cities and the recognition of people's behavior and their willingness to choose teleworking can be compared this present research and its results. 


\section{REFERENCES}

1. Zhu, P. (2013). Telecommuting, household commute and location choice. Urban Studies, 50(12), 2441-2459.

https://doi.org/10.1177/0042098012474520

2. Melo, P. C., \& e Silva, J. D. A. (2017). Home telework and household commuting patterns in Great Britain. Transportation Research Part A: Policy and Practice, 103, 1-24.

https://doi.org/10.1016/i.tra.2017.05.011

3. Salomon, I. (1986). Telecommunications and travel relationships: a review. Transportation Research Part A: General, 20(3), 223-238. https://doi.org/10.1016/0191-2607(86)90096-8

4. Botzoris, G., Profillidis, V., \& Galanis, A. (2016). Teleworking and sustainable transportation in the era of economic crisis. In 5th International Virtual Conference on Information and Telecommunication Technologies (ICTIC 2016), Žilina, Slovakia.

https://doi.org/10.18638/ictic.2016.5.1.295

5. Moeckel, R. (2017). Working from Home: Modeling the Impact of Telework on Transportation and Land Use. Transportation Research Procedia, 26, 207-214.

https://doi.org/10.1016/i.trpro.2017.07.021

6. Lila, P. C., \& Anjaneyulu, M. V. L. R. (2017). Networkwide Impact of Telework in Urban Areas: Case Study of Bangalore, India. Journal of Transportation Engineering, Part A: Systems, 143(8), 05017004.

https://doi.org/10.1061/JTEPBS.0000061

7. Łabędowicz, J., \& Urbanek, A. (2017). Do Information and Communications Technologies influence transport demand? An exploratory study in the European Union. Transportation Research Procedia, 25, 2660-2676.

https://doi.org/10.1016/i.trpro.2017.05.156

8. Elldér, E. (2017). Does telework weaken urban structure-travel relationships?. Journal of Transport and Land Use, 10(1), 187-210.

9. Ge, J., Polhill, J. G., \& Craig, T. P. (2018). Too much of a good thing? Using a spatial agent-based model to evaluate "unconventional" workplace sharing programmes. Journal of Transport Geography, 69, 83-97.

https://doi.org/10.1016/j.jtrangeo.2018.04.005
10.Zhu, P., Wang, L., Jiang, Y., \& Zhou, J. (2018). Metropolitan size and the impacts of telecommuting on personal travel. Transportation, $1-30$.

https://doi.org/10.1007/s11116-017-9846-3

11.Shabanpour, R., Golshani, N., Tayarani, M., Auld, J., \& Mohammadian, A. K. (2018). Analysis of telecommuting behavior and impacts on travel demand and the environment. Transportation Research Part D: Transport and Environment, 62, 563-576.

https://doi.org/10.1016/j.trd.2018.04.003

12. de Abreu e Silva, J., \& Melo, P. C. (2018). The Effects of Home-Based Telework on Household Total Travel of One and Two Worker British Households (No. 18-04968).

https://doi.org/10.1016/j.jtrangeo.2018.10.009

13.Silva, J. D. A., \& Melo, P. C. (2018). Home telework, travel behavior, and land-use patterns: A path analysis of British single-worker households. Journal of Transport and Land Use, 11(1). https://doi.org/10.5198/jtlu.2018.1134

14.Akbary-Borng, M., Mosavi, A. S., \& Azami, M. (2018). Reviewing the Viewpoint of Managers and Librarians of Public Libraries in Kerman Province towards Teleworking: Identifying the Benefits, Obstacles and Ways of Expansion. Research on Information Science and Public Libraries, 23(4), 487-502.

15.Giovanis, E. (2018). The relationship between teleworking, traffic and air pollution. Atmospheric Pollution Research, 9(1), 1-14. https://doi.org/10.1016/j.apr.2017.06.004

16. Suarlan, S. (2018). Teleworking for Indonesian Civil Servants: Problems and Actors. Bisnis \& Birokrasi Journal, 24(2). 